\title{
ANALISIS TERJEMAHAN EKSPRESI SOLIDARITAS DAN KEBERPIHAKAN DALAM TEKS KONFERENSI PERS DAN SIARAN MEDIA TENTANG EKSEKUSI NARAPIDANA (PENDEKATAN TEORI APPRAISAL)
}

\author{
Alifa Hanifati Irlinda ${ }^{1}$, Riyadi Santosa ${ }^{2}$, Diah Kristina ${ }^{3}$ \\ ${ }^{1}$ Magister Linguistik Penerjemahan Pascasarjana UNS \\ ${ }^{2}$ Professor in SFL at Universitas Sebelas Maret, Surakarta, Indonesia \\ ${ }^{3}$ Universitas Sebelas Maret, Surakarta, Indonesia \\ irlindaalifa@gmail.com
}

\begin{abstract}
This study aims to explain the way appraisal resources in the political text are mediated in the translation. The exploitation of appraisal resources in the source text would determine the pattern used by text speakers in realizing text's purposes while anticipating and controlling the effect after these purposes are achieved. Furthermore, these evaluations are translated using various translation techniques, which would determine the quality as well as translators' interference and distortion in balancing the text's purposes and its aftermath.

This descriptive qualitative study include the source of data that are four transcripts of press conference and media release from Australian government regarding Chan and Sukumaran's executions in English, and the translation in Bahasa Indonesia. There are 349 data of appraisal resources divided into solidarity and alignment expressions, selected through purposive sampling. Data were then classified into the respective appraisal categories, identified by the translation techniques, and analyzed to find the relation with the translation quality.

Majority of translation techniques used in solidarity expressions are Established Equivalent, Borrowing, and Literal that keep most of appraisal categories equivalent to those in the source text; while in alignment expressions are Established Equivalent, Reduction, and Modulation resulting in more deviations in the target text. Interference and distortion are used by translators, consciously or not, to realize text's goals while minimizing the aftermaths of negative evaluations.
\end{abstract}

Keywords: appraisal, translation technique, translation quality, solidarity, alignment, interference, distortion

\section{PENDAHULUAN}

\section{Latar Belakang}

Sebagai medium yang membentuk dan dibentuk oleh proses sosial, bahasa mengandung aspek dialogis (Martin \& White, 2005; White \& Sano, 2006). Aspek dialogis ini mempertahankan, memproduksi ulang, atau mengubah hubungan partisipan 
teks. Aspek-aspek tersebut dapat diidentifikasi dengan piranti appraisal. Di dalam terjemahan, piranti appraisal dapat luput dari perhatian penerjemah. Sebagai akibatnya, latar belakang dialogis dan posisi partisipan teks dapat berubah di dalam teks terjemahan.

Sejauh ini, solidaritas dan keberpihakan hanya merujuk terhadap sistem Engagement (White, 1998; White, 2002; Martin \& Rose, 2003), belum mencakup Attitude dan Graduation. Sebagian besar penelitian mengenai appraisal berfokus terhadap karya fiksi (Hidayani, 2006; Su-trisno, 2013; Umam, 2014). Implikasi penelitian-penelitian tersebut jarang ditemukan di dunia nyata, dan belum dapat menjelaskan fungsi setiap kategori appraisal di dalam konteks tertentu. Sejumlah penelitian juga menggunakan data yang tidak berasal langsung dari penuturnya: wacana media dengan penghilangan dan parafrase (Suherman, 2008; Ertyas, 2011; Muftihah, 2011; Prasetyo, 2011; Bánhegyi, 2012; Hong, 2012). Maka, penelitian ini menggunakan transkrip konferensi pers dan siaran media dengan lokusi langsung dari penutur dan memiliki pengaruh langsung terhadap nilai solidaritas dan keberpihakan di dunia nyata.

Penelitian terdahulu juga belum memberikan definisi jelas mengenai pergeseran dan perubahan makna pada terjemahan piranti appraisal, serta alasan piranti appraisal dan teknik penerjemahan tertentu dipilih (Hong, 2012; Sutrisno, 2013; Umam, 2014). Penelitian-penelitian tersebut juga belum membahas pemosisian penutur dan audiens dengan tujuan tertentu dengan Attitude, Graduation, dan Engagement. Karena itu, penelitian ini akan menjelaskan cara pemosisian diper-tahankan, digeser, diubah, dihilangkan, atau ditambah di dalam terjemahan, serta dampaknya pada teks sasaran. 


\section{Tujuan Penelitian}

Tujuan penelitian ini dapat diformulasikan sebagai berikut:

1. Mengidentifikasi teknik penerjemahan piranti appraisal dan dampaknya terhadap kualitas terjemahan.

2. Memaparkan piranti appraisal yang merealisasikan nilai solidaritas dan keberpihakan pada teks konferensi pers dan siaran media dalam Bahasa Inggris dan terjemahannya dalam Bahasa Indonesia.

3. Mengelaborasi posisi partisipan berdasarkan kerangka teori appraisal dan menjelaskan jika pemosisian tersebut dipertahankan, digeser, diubah, dihilangkan, atau ditambah di dalam teks sasaran.

\section{Kajian Pustaka}

Tinjauan Pustaka difokuskan terhadap: (1) teknik penerjemahan dan kualitas terjemahan; serta (2) kerangka teori appraisal dan konvensi teks.

\section{a. Penerjemahan}

Dalam proses rekonstektualisasi (pada terjemahan), pesan dan argumen akan ditransformasikan dan disaring (Schäffner, 2010; Blackledge, 2005). Di samping transformasi linguistik, rekontekstualisasi dapat juga mencakup penghilangan, penambahan, dan reformulasi lain dari teks sumber.

Hal tersebut sejajar dengan proposisi Munday (2012) bahwa sudut panjang subyektif penerjemah berkontribusi terhadap aspek linguistik di dalam teks sasaran. Penerjemahan dipandang sebagai medium untuk menyaring pendapat personal dan politis. Pendapat-pendapat tersebut diproses dan seringkali diubah secara subyektif oleh penerjemah. Hendrastuti (2013) mengklasifikasikan terjemahan bahasa evaluasi yang 
dihasilkan subyektifitas penutur: mediasi (evaluasi diterjemahkan dengan akurat), interferensi (terjemahan melenceng karena kompetensi bilingual penerjemah yang kurang mumpuni), dan distorsi (terjemahan mengalami deviasi akibat intervensi ideologis penerjemah).

Molina dan Albir (2002) membedakan 18 teknik penerjemahan: Adaptasi, Amplifikasi, Peminjaman, Kalke, Kompensasi, Deskripsi, Discursive Creation, Kesepadanan Lazim, Generalisasi, Amplifikasi Linguistik, Kompresi Linguistik, Literal, Modulasi, Partikularisasi, Reduksi, Transposisi, dan Variasi. Penggunaan teknik penerjemahan menentukan kualitas terjemahan yang penilaiannya dapat diterapkan pada level mikro (unit linguistik) dan level makro (konvensi teks) (Nababan, Nuraeni \& Sumardiono, 2012).

Terjemahan yang berkualitas ditandai oleh isi terjemahan yang akurat, berterima, dan terbaca. Berdasarkan keakuratan terjemahan bahasa evaluasi, Hendrastuti (2013) berargumen bahwa mediasi penerjemah menghasilkan terjemahan akurat; interferensi kurang akurat; dan distorsi tidak akurat.

b. Kerangka Teori Appraisal dan Konvensi Teks

Kerangka teori appraisal terbagi ke dalam: Attitude, Graduation, dan Engagement (White, 1998; Martin \& Rose, 2003; Martin \& White, 2005). Attitude Affect berhubungan dengan cara penutur mengungkapkan perasaan positif atau negatif.

Table 1. Jenis-jenis Affect

\begin{tabular}{lll}
\hline Affect & Positive & Negative \\
\hline dis/inclination & [desire] suggest, request, long & [fear] tremble, shudder, wary, \\
& for & fearful \\
un/happiness & [cheer] chuckle, laugh, rejoice & [misery] whimper, cry, sad \\
& [affection] shake hand, hug, love & [antipathy] dislike, hate, abhor \\
in/security & [confidence] confident, assured & [disquiet] restless, uneasy, \\
& [trust] commit, entrust, confident & anxious, \\
& in & [surprise] faint, startled, jolted
\end{tabular}


dis/satisfaction [interest] attentive, busy, engrossed [pleasure] satisfied, impressed [ennui] yawn, tune out, flat, stale [displeasure] scold, angry, sick of

Diadaptasi dari Martin \& Rose (2003)

Attitude Judgment mencakup evaluasi terhadap karakter atau perilaku. Attitude Appreciation meliputi evaluasi terhadap fenomena (semiotik atau natural) berdasarkan cara fenomena tersebut dipandang di dalam konteks tertentu.

Judgment dan Appreciation sangat terikat dengan konteks institusional. Hal ini disebabkan penilaian didasarkan pada pandangan yang umum dan tidak umum menurut nilai-nilai bersama (Martin \& White, 2005). Unit linguistik yang termasuk Judgment dan Appreciation ditentukan pertanyaan pada Tabel 2 dan 3

Table 2. Types of Judgment

Social Esteem Social Sanction

normality: 'how special?' veracity [truth]: 'how honest?'

capacity: 'how capable?' propriety [ethics]: 'how far beyond reproach?'

tenacity: 'how dependable?'

Diadaptasi dari Martin \& Rose (2003).

Judgment terbagi ke dalam dua jenis evaluasi: pengakuan sosial (Social Esteem) dan sangsi sosial (Social Sanction) sebagai konsekuensi. Jika memiliki terlalu banyak pengakuan sosial negatif, seseorang mungkin perlu mengunjungi psikolog; jika memiliki terlalu banyak sangsi sosial negatif, seseorang mungkin perlu berurusan dengan pengacara (Martin \& White, 2005).

Table 3. Types of Appreciation

\begin{tabular}{lll}
\hline Reaction & Composition & Valuation \\
\hline $\begin{array}{l}\text { impact: 'did it grab } \\
\text { me?' }\end{array}$ & $\begin{array}{l}\text { balance: 'did it hang } \\
\text { together?' }\end{array}$ & $\begin{array}{l}\text { valuation: 'was it } \\
\text { quality: 'did I like it?' }\end{array}$ \\
& $\begin{array}{l}\text { complexity: 'was it hard to } \\
\text { follow?' }\end{array}$ & \\
\hline
\end{tabular}

Diadaptasi dari Martin and Rose (2003)

Penutur menyebutkan sumber tuturan dan sikap mental di dalam konstruksi teks dan menghadapi audiens. Hal tersebut merupakan ranah Engagement. Bakhtin (1982) dan Voloshinov (1995) (di dalam Martin \& White, 2005) menyebutkan bahwa setiap tuturan, baik lisan maupun tertulis, memiliki sifat dialogis; dipengaruhi dan merujuk terhadap wacana yang telah ada. Engagement berfokus terhadap pengakuan dan interaksi penutur dengan gagasan-gagasan terdahulu, sekaligus mengantisipasi 
respon dari audiens. Di samping itu, Engagement juga mencakup monoglossia, yaitu tuturan tanpa lokusi intersubjektif (lihat Gambar 1).

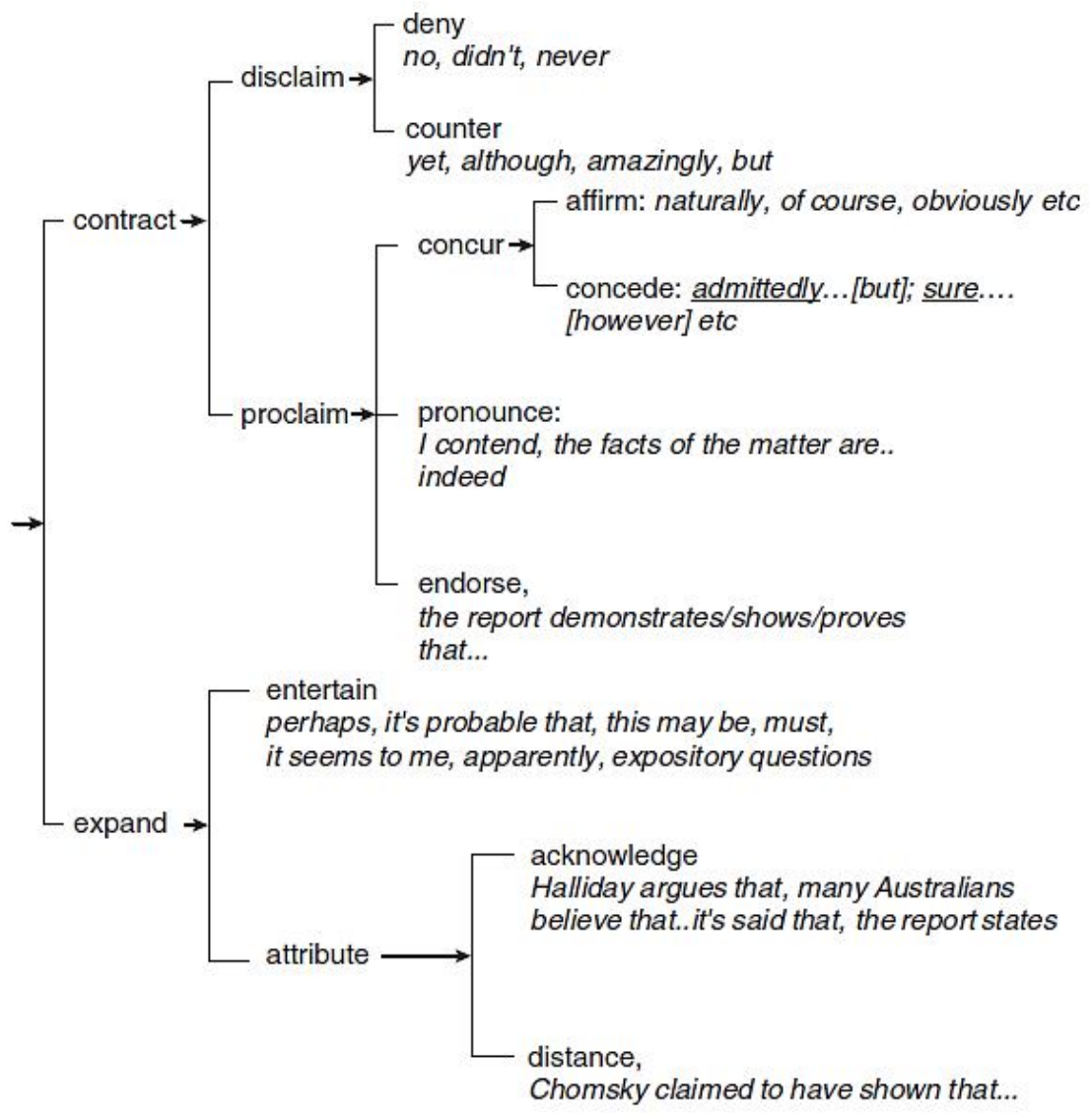

Gambar 1. Sistem Engagement (Martin \& White, 2005) 
Dengan nilai keberpihakan/ketidakberpihakan Engagement Kontraksi Dialogis, audiens diminta memvalidasi evaluasi penutur. Audiens dapat berpihak dengan kepercayaan dan nilai tertentu yang diajukan penutur. Di dalam konteks dialogis, solidaritas pada Ekspansi Dialogis berarti mengakui gagasan alternatif di dalam wacana dan mengantisipasi pendapat kontras yang mungkin muncul.

Kontraksi Dialogis Disclaim digunakan ketika proposisi yang diajukan mengkontraskan dan menolak gagasan tertentu; Proclaim digunakan digunakan untuk menunjukan validitas dari suatu proposisi.

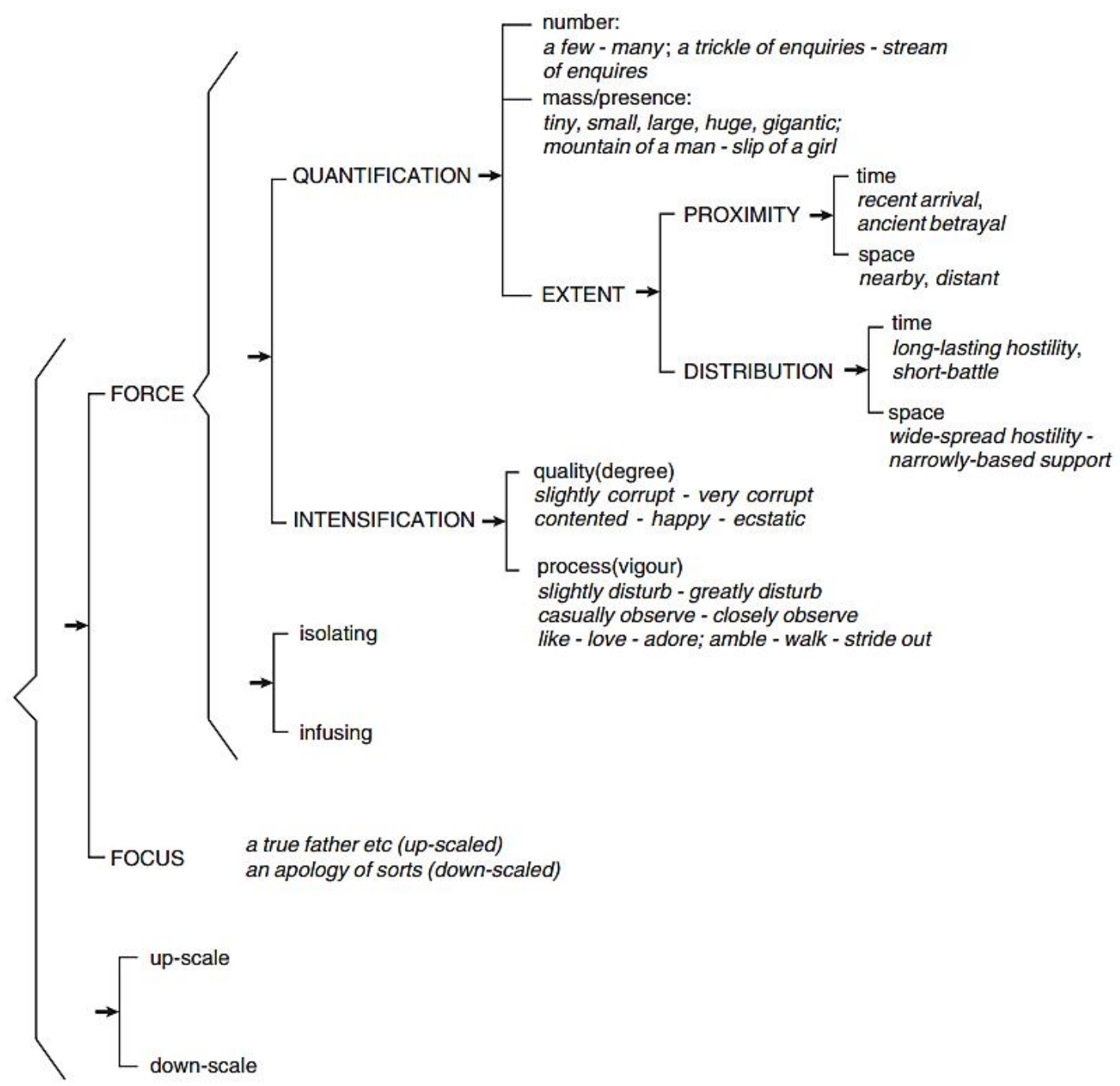

Gambar 2. Sistem Graduation force dan focus (Martin \& White, 2005) 
Kontraksi Dialogis memungkinkan penutur menutup atau mempersempit ruang dialogis, mencegah timbulnya gagasan lain.

Ekspansi Dialogis Entertain mengakui bahwa setiap proposisi didasari oleh subyektifitas individu, menempatkan proposisi tersebut di tengah sejumlah gagasan lain. Attribute digunakan ketika penu-tur menghubungkan intersubyektifitas proposisi terhadap sumber yang berada di luar teks. Ekspansi Dialogis menempati sebagian kecil dari ruang dialogis, menga-kui gagasan alternatif dan kontrastif.

Salah satu faktor yang menentukan makna atitudinal teks adalah tingkatantingkatan unit linguistiknya. Graduation dapat digunakan untuk menggolongkan skala tinggi atau rendah dari Affect, Judgment, dan Appreciation (lihat Gambar 2). Menambah penjelasan Martin dan Rose (2003), Martin dan White (2005) berpendapat bahwa piranti Engagement dapat ditempatkan di dalam skala amplifikasi. Sikap mental dan pemosisian audiens dapat dikonstruksikan dengan lebih atau kurang kuat berdasarkan nilai keberpihakan dan solidaritas.

Bahasa evaluasi memiliki dua polar amplifikasi: berdasarkan intensitas atau angka (Force); dan berdasarkan prototipikalitas dan batasan kategori semantik (Focus). Focus biasanya ditemukan pada realitas linguistik yang tidak dapat diskalakan secara eksperiensial.

Konvensi teks dapat diidentifikasi melalui leksikogrammar, semantik wacana, ideologi, dan struktur retoris. Sifat konvensional ini kemudian dikonstruksikan di dalam struktur genre teks. Hal tersebut terjadi secara berulang-ulang sehingga membangun genre yang memiliki standar, fungsi, dan tujuan tertentu. Bhatia (1993) menjelaskan bahwa genre adalah aktifitas komunikatif yang dipahami bersama. Genre mengatur kontribusi penulis atau penutur yang berhubungan dengan intensi dibuatnya teks, 
pemosisian partisipan teks, dan nilai formal dan fungsional. Di dalam kerangka teori appraisal, genre berkorelasi terutama dengan sistem Engagement.

\section{METODE PENELITIAN}

Metode yang digunakan adalah kualitatif dan deskriptif karena meneliti fenomena yang jamak, dikonstruksi, holistik, dan terikat konteks (Lincoln \& Guba, 1985; Strauss \& Corbin, 2003). Sumber data meliputi empat transkrip konferensi pers dan siaran media dari situs jaringan pemerintah Australia; dan terjemahannya dari situs jaringan Kedutaan Besar Australia untuk Indonesia. Penutur teks ada-lah PM Tony Abbott dan MLN Julie Bishop mengenai eksekusi yang dihadapi oleh dua warga negara Australia, Andrew Chan dan Myuran Sukumaran.

Rater berkontribusi untuk menilai kualitas terjemahan. Data meliputi 349 piranti appraisal sebagai ekspresi solidaritas (terhadap Indonesia) dan ekspresi keberpihakan (terhadap dua narapidana dan keluarganya), di dalam bahasa Inggris dan Bahasa Indonesia.

Data appraisal dipilih melalui purposive sampling berdasarkan kriteria tertentu (Patton, 1980; Lincoln \& Guba, 1985). Kuesioner dan hasil diskusi kelompok terarah dengan para rater juga digunakan sebagai data. Data divalidasi dengan teknik triangulasi berdasarkan sumber data (dokumen; dan rater sebagai responden dan informan) dan metode (Lincoln \& Guba, 1985). Metode berbeda digunakan untuk memproses data dari dokumen dan informan: analisis konten (domain, taksonomi, komponensial, dan analisis tema budaya) (Spradely, 2006); diskusi (dengan validator); serta kuesioner dan diskusi kelompok terarah (dengan para rater sebagai responden dan informan). 


\section{HASIL DAN PEMBAHASAN}

\section{Penggunaan Piranti Appraisal}

Ekspresi solidaritas menggunakan piranti Attitude untuk menyesuaikan kepentingan Australia dengan Indonesia; juga mengungkapkan nilai-nilai bersama kedua negara. Ekspresi solidaritas sebagian besar dibangun oleh Affect positif (Desire; Satisfaction; Admiration; dan Happiness: Affection), yang mengandung harapan penutur mengenai kelanjutan hubungan Australia-Indonesia dan menyatakan rasa hormat terhadap Indonesia. Setelah Affect, Appreciation positif (Valuation; Composition: Balance; dan Reaction: Impact) hadir dengan jumlah signifikan. Sebagian besar Appreciation positif digunakan untuk mengevaluasi pentingnya hubungan bilateral Australia-Indonesia. Judgment: Propriety negatif lebih mendominasi dibanding Propriety positif. Kategori Propriety negatif mengungkapkan sangsi sosial Chan dan Sukumaran sebagai akibat dari kejahatan narkotika yang mereka perbuat.

Piranti Attitude ekspresi keberpihakan digunakan untuk mempengaruhi dan menarik keberpihakan audiens. Berbeda dengan Attitude ekspresi solidaritas, sebagian besar ekspresi keberpihakan merupakan Appreciation negatif (Valuation; Composition: Complexity; Reaction: Impact; Reaction: Quality). Piranti Appreciation negatif tersebut menyatakan kekejaman eksekusi yang dianggap tidak perlu, menyebabkan saat-saat yang buruk bagi keluarga narapidana dan hubungan bilateral. Affect negatif (Unhappiness: Misery; Dissatisfaction: Displeasure; Unhappiness: Antipathy; Insecurity: Disquiet) juga dominan. Affect negatif digunakan untuk mengungkapkan rasa sesal terhadap hukuman mati; ketidaksenangan terhadap perlakuan pemerintah 
Indonesia; dan keprihatinan bahwa rehabilitasi kedua narapidana tidak dipertimbangkan.

Kategori Judgment: Tenacity positif menutupi kategori negatif mengenai "kegagalan" pemerintah Indonesia. Tenacity positif menyebabkan ekspresi keberpihakan lebih berfokus terhadap sisi positif kedua narapidana dibandingkan evaluasi negatif terhadap pemerintah Indonesia, audiens yang diantisipasi penutur.

Dominasi Appreciation negatif pada ekspresi keberpihakan memungkinkan penutur menghindari evaluasi langsung terhadap audiens yang sebenarnya dituju (e.g. Judgment negatif terhadap pemerintah Indonesia). Appreciations pada beberapa kasus berupa kalimat pasif, sehingga mendisasosiasikan secara sementara pihak yang dituju dari evaluasi negatif. Affect negatif membantu penutur lebih memfokuskan evaluasinya terhadap perasaan dibandingkan terhadap karakter pihak yang dimaksud.

Penggunaan Judgment positif semakin mengkonfirmasi pilihan penutur untuk menghindari evaluasi karakter secara negatif, yang akan mengganggu hubungan Australia-Indonesia. Hal ini sejalan dengan pernyataan Lee (2015) bahwa hubungan bilateral Australia-Indonesia terlalu penting untuk dipertaruhkan.

Dominasi subsistem appraisal yang berseberangan antara ekspresi solidaritas dan keberpihakan juga ditemukan pada Engagement. Ekspresi solidaritas dibentuk oleh asersi monogloss, Ekspansi Dialogis, dan Kontraksi Dialogis secara berurutan dari yang paling dominan. Struktur argumen pada keempat teks eksposisi didominasi oleh asersi monogloss. Asersi monogloss hadir sebagai informasi yang diasumsikan telah dimengerti dan diterima oleh seluruh partisipan teks. Dominasi asersi monogloss di dalam ekspresi solidaritas mengimplikasikan bahwa nilai solidaritas di dalam teks dianggap telah diketahui partisipan teks dan sedang tidak didiskusikan kebenarannya. 
Hal ini sejalan dengan gagasan Martin dan White (2005). Proposisi yang dianggap telah diterima tersebut memiliki dampak ideologis terhadap persetujuan audiens teks: bahwa nilai solidaritas telah dimiliki bersama antara penutur (peme-rintah Australia) dengan pemerintah dan publik Indonesia.

Dalam hubungannya dengan pemosisian penutur dan pihak yang diwakili, Ekspansi dan Kontraksi Dialogis sebagian besar didistribusikan pada struktur thesis dan reiteration/recommendation pada keempat teks eksposisi. Ekspansi Dialogis mencakup Entertain, yang menempatkan sumber lokusi di dalam ruang dialogis yang terbuka untuk diskusi dengan audiens (i.e. pemerintah atau publik Indonesia); dan Acknowledge, yang mengatributkan evaluasi terhadap sumber di luar teks dan sekaligus mengimplikasikan sikap terbuka penutur terhadap pendapat alternatif atau kontrastif.

Kontraksi Dialogis terdiri dari Deny untuk menolak evaluasi/nilai yang sebelumnya telah diakui penutur; Counter untuk mengawali gagasan kontrastif terhadap proposisi yang telah diajukan sebelumnya serta menolak harapan normal penutur dan audiens; Pronounce untuk menekankan lokusi sumber tuturan yang merealisasikan nilai solidaritas; dan Concur untuk mengungkapkan lokusi subyektif mengenai pengetahuan yang penutur perkirakan telah dimengerti bersama dengan audiens yang dituju.

Ekspresi keberpihakan didominasi oleh Kontraksi Dialogis, asersi monogloss, dan Ekspansi Dialogis secara berurutan. Kontraksi Dialogis meliputi Counter untuk mengkontraskan evaluasi positif dengan situasi negatif yang sesungguhnya terjadi dan ungkapan sesal terhadap terjadinya eksekusi; Pronounce untuk menyatakan dampak eksekusi terhadap hubungan Australia-Indonesia, juga menyatakan kekejaman eksekusi; Deny untuk menolak gagasan bahwa hukuman mati adalah perlu serta menolak gagasan bahwa representasi Australia diperhatikan oleh Indonesia; Concur untuk menampilkan 
lokusi intersubyektif mengenai pemahaman bersama bahwa keluarga narapidana sedang melalui masa-masa yang sulit.

Ekspansi Dialogis ekspresi keberpihakan hadir sebagai Entertain untuk menyisipkan subyektifitas mengenai hukuman ganda terhadap kedua narapidana, serta mengenai representasi Australia yang "apparently" tidak diperhatikan; Acknowledge untuk mengatributkan tuturan kepada partisipan di dalam dan di luar teks dan memiliki status yang tinggi pada wacana yang sedang dibahas; dan Distance untuk mendisasosiasikan penutur dari evaluasi negatif, seperti pemboikotan Indonesia dan pemotongan dana bantuan Australia untuk Indonesia.

Dominasi Kontraksi Dialogis dan asersi monogloss pada ekspresi keberpihakan dinilai sesuai pada tempatnya karena genre eksposisi memang memiliki tujuan mempengaruhi audiensnya. Terlebih lagi, ekspresi keberpihakan dimaksudkan untuk menunjukkan sikap mental dan ideologi penutur lebih jelas daripada ekspresi solidaritas pada konteks ini. Tujuan empat teks eksposisi ini adalah untuk mengungkapkan ketidaksenangan Australia terhadap hukuman mati Chan dan Suku-maran.

Dominasi Kontraksi Dialogis dinilai sebagai usaha penutur mendapatkan keberpihakan audiens terhadap tujuan awal teks. Ekspresi solidaritas dikonstruksikan untuk menyeimbangkan penggunaan dan dampak evaluasi-evaluasi negatif tersebut.

Beberapa kategori appraisal hanya muncul pada ekspresi keberpihakan. Kategori-kategori tersebut dapat dilihat sebagai strategi menyamarkan dan mendisasosiasikan penutur dari evaluasi negatif yang dapat mengganggu hubungan dengan Indonesia. Salah satu kategori tersebut adalah Distance. Melalui distancing, audiens akan melihat bahwa penutur (PM Tony Abbott dan MLN Julie Bishop) tidak memiliki kontrol akan turbulensi hubungan bilateral Australia-Indonesia. 
Piranti Graduation amplifikasi tinggi (up-scaling) mendominasi ekspresi solidaritas dan keberpihakan. Amplifikasi up-scaling lebih banyak hadir pada ekspresi solidaritas dibandingkan pada ekspresi keberpihakan. Hal ini mengindikasikan interaksi lebih kuat antara penutur dengan audiens pada ekspresi solidaritas. Maka, partner dialogis yang mungkin diantisipasi penutur adalah pemerintah dan publik Indonesia.

Amplifikasi up-scaled ekspresi solidaritas dapat dipandang sebagai strategi yang Abbott untuk memperbaiki reputasi internasionalnya: Pada 18 Februari 2015, di depan media internasional, Abbott menyatakan bahwa Indonesia tidak boleh melupakan bantuan Australia ketika tsunami melanda Aceh pada 2004. Abbott juga menyebutkan bahwa Indonesia harus "reciprocate" dengan menyelamatkan nyawa Chan dan Sukumaran (Hurst untuk The Guardian, 2015). Pernyataan ini memicu backlash dari daerah-daerah di Indonesia dan masyarakat internasional, termasuk masyarakat Australia sendiri.

Piranti Graduation yang menandai perbedaan antara ekspresi solidaritas dan keberpihakan adalah Intensification: Quality dan Intensification: Process. Pada ekspresi solidaritas, piranti Intensification: Quality lebih dominan dibandingkan Intensification: Process. Dengan Intensification: Quality, amplifikasi dikonstruksikan secara langsung sebagai epitet atau intensifier. Penutur cenderung secara terang-terangan mengungkapkan amplifikasi up-scaled. Hal tersebut bertolak belakang dengan penggunaan Intensification: Process, yang lebih dominan pada ekspresi keberpihakan. Dengan Intensification: Process, amplifikasi hadir sebagai proses atau verba sehingga nilai up-scaled-nya tidak dapat diobservasi secara langsung.

Kategori appraisal lain yang hanya muncul pada ekspresi keberpihakan adalah Graduation Intensification: Metaphor. Penggunaan metafora dapat menyamarkan 
evaluasi negatif dan partisipan yang sedang dinilai. Hal ini terjadi secara otomatis karena piranti tersebut pada umumnya hadir sebagai kategori Appreciation atau Affect, bukan Judgment. Di samping itu, metafora biasanya diatributkan terhadap subyek impersonal, menyembunyikan pihak yang dituju.

Penelitian ini memberikan penambahan terhadap gagasan Martin dan White (2005) dan Hong (2012) mengenai nilai solidaritas dan keberpihakan pada heteroglossia. Penambahan tersebut meliputi temuan bahwa piranti Attitude juga dapat digunakan sebagai alat tolak ukur dalam menemukan tujuan penggunaan piranti Engagement dan Graduation di dalam teks. Untuk mengidentifikasi dampak dari asersi monogloss, Kontraksi Dialogis, dan Ekspansi Dialogis, analis teks dapat merujuk kepada evaluasi yang direalisasikan oleh piranti Attitude.

\section{Penggunaan Teknik Penerjemahan}

Piranti appraisal dapat dipertahankan, dihilangkan, ditambah, digeser, atau diubah di dalam teks sasaran. Pergeseran terjadi ketika piranti appraisal diterjemahkan ke dalam kategori yang sama seperti pada teks sumber, namun subkategorinya berbeda. Kemudian, pergeseran terjadi ketika piranti appraisal diterjemahkan ke dalam kategori yang sama seperti pada teks sumber, namun sub-kategorinya berbeda atau amplifikasinya bergeser. Sebagai contoh, "most remarkable way" diterjemahkan menjadi "cara yang sangat bagus."

Perubahan terjadi ketika piranti appraisal di dalam teks sasaran termasuk ke dalam kategori yang berbeda dari teks sumber. Sebagai contoh, evaluasi "dismay" pada datum ekspresi keberpihakan termasuk ke dalam Affect Dissatisfaction: Displeasure. 
Leksis tersebut diterjemahkan menjadi "terkejut," yang termasuk ke dalam Insecurity: Surprise.

Di dalam teks terjemahan ekspresi solidaritas, teknik Amplifikasi menghasilkan penambahan subkategori Concur. Penambahan ini berkontribusi mengungkapkan subyektifitas penutur terhadap pengetahuan yang diperkirakan telah dimiliki bersama dengan audiens. Teknik Amplifikasi juga menambah piranti Inten-sification: Quality dengan amplifikasi up-scaled. Teknik tersebut menaikkan amplifikasi Concur pada teks sasaran.

Penambahan tersebut menghasilkan penurunan sifat taken-for-granted yang dimiliki oleh ekspresi solidaritas (i.e. nilai solidaritas yang diperkirakan telah diterima oleh seluruh partisipan teks). Penambahan tersebut juga memicu timbulnya ruang dialogis terbatas, mengimplikasikan bahwa ada audiens yang keberpihakannya harus dimenangkan. Penambahan tersebut melancarkan usaha meningkatkan nilai solidaritas teks sasaran. Meskipun demikian, penerjemah tetap menjaga dominasi asersi monogloss beserta sifat taken-for-granted-nya.

Teknik Reduksi di dalam ekspresi solidaritas menghilangkan piranti Composition: Complexity; dan Intensification: Quality up-scaled di dalam teks sasaran. Empat kasus penghilangan tersebut menurunkan nilai solidaritas. Teknik Reduksi, Generalisasi, Modulasi, Transposisi, dan Amplifikasi menggeser sejumlah piranti Graduation up-scaled menjadi down-scaled di dalam teks terjemahan.

Teknik Modulasi mengubah piranti Pronounce menjadi Counter pada ekspresi solidaritas, mengubah deklarasi penutur menjadi lokusi yang mengandung harapan normal penutur dan audiens di dalam teks terjemahan. Namun, berada di bawah kategori Kontraksi Dialogis, Counter di dalam teks terjemahan masih mengandung tuturan yang 
tidak dapat ditawar dan memiliki harga interpersonal tinggi untuk pihak yang ingin mengajukan gagasan alternatif atau kontrastif.

Teknik Reduksi tidak hanya menghasilkan penghilangan piranti appraisal; dapat menggeser amplifikasinya (e.g. dari up-scaled menjadi down-scaled). Pergeseran tersebut disebabkan oleh penghilangan beberapa elemen teks sumber. Maka, meskipun piranti Attitude dan Engagement telah sepadan pada teks sasaran, piranti Graduation yang mengiringinya dapat bergeser. Teknik Reduksi juga dapat mengubah kategori appraisal dengan menghilangkan beberapa informasi dari Dissatisfaction: Displeasure "dismayed" menjadi "terkejut" yang termasuk Insecurity: Surprise di dalam teks sasaran.

Di dalam terjemahan ekspresi keberpihakan, teknik Modulasi, Reduksi, dan Partikularisasi menggeser beberapa piranti Graduation up-scaled menjadi down-scaled, dan sebaliknya. Pergeseran amplifikasi up-scaled menjadi down-scaled di dalam ekspresi keberpihakan justru meningkatkan nilai solidaritas di dalam teks terjemahan. Pemosisian penutur berada lebih jauh dari yang seharusnya pada teks sasaran. Teknik Reduksi menghilangkan Judgment: Propriety; Pronounce; Pronounce up-scaled; Focus up-scaled; Intensification: Quality up-scaled; dan Intensification: Quality down-scaled. Penghilangan tersebut mengurangi nilai keberpihakan sampai batas tertentu. Kasus penghilangan dan pergeseran terjadi lebih sering pada ekspresi keberpihakan, sehingga mendukung nilai solidaritas lebih dari yang seharusnya di dalam teks sasaran.

Teknik Partikularisasi pada terjemahan ekspresi keberpihakan juga mengubah piranti Insecurity: Disquiet menjadi Dissatisfaction: Displeasure. Teknik Modulasi mengubah Entertain "apparently not taken into account" menjadi Counter "ternyata tidak diperhitungkan." Teknik Amplifikasi menghasilkan empat kasus penambahan 
Counter, Deny, dan Intensification: Quality up-scaled. Penambahan piranti Counter dan Deny pada teks sasaran mengurangi ruang dialogis yang memang sudah sempit di dalam teks sumber; merekonstruksi prosodi teks.

Penambahan piranti Kontraksi Dialogis tersebut dianggap sesuai tempatnya. Hal ini disesebabkan: (1) ekspresi keberpihakan memang selalu berusaha menarik keberpihakan audiens; (2) piranti Kontraksi Dialogis memang telah mendominasi ekspresi keberpihakan di dalam teks sumber; (3) sifat persuasif teks eksposisi akan selalu berusaha mempengaruhi audiens dengan proposisi yang dianggap valid secara intersubyektif.

Pergeseran amplifikasi up-scaled menjadi down-scaled lebih banyak terjadi daripada deviasi yang menambah nilai keberpihakan. Meskipun sebagian besar teknik penerjemahan berhasil mempertahankan piranti appraisal, teknik-teknik lain menyebabkan peningkatan nilai solidaritas di dalam teks terjemahan ekspresi keberpihakan. Kasus pergeseran, penghilangan, pengubahan, dan penambahan terjadi lebih sering pada teks terjemahan ekspresi keberpihakan. Di samping itu, rasio piranti appraisal ekspresi solidaritas yang dipertahankan lebih besar diban-dingkan dengan ekspresi keberpihakan. Maka, evaluasi, sikap mental penutur, dan pemosisian audiens diubah lebih sering pada ekspresi keberpihakan.

\section{Kualitas Terjemahan}

Nilai keakuratan tertinggi terjemahan piranti appraisal ekspresi solidaritas dan keberpihakan adalah 3; dan yang terendah adalah 2 pada ekspresi solidaritas dan 1 pada ekspresi keberpihakan. Nilai keberterimaan paling tinggi pada ekspresi solidaritas dan keberpihakan adalah 3; dan yang terendah adalah 2. Unit linguistik yang dipindahkan ke 
dalam teks sasaran pada beberapa kasus lebih difokuskan pada leksis atau frasa. Maka, meskipun teknik Kesepadanan Lazim teridentifikasi, terjemahannya sering tidak memiliki kolokasi tepat dengan evaluasi lain yang hadir pada tuturan yang sama di dalam konteks yang sama.

Piranti appraisal ekspresi solidaritas diterjemahkan secara lebih akurat dibandingkan pada ekspresi keberpihakan. Hal ini dapat disebabkan oleh kompetensi penerjemah yang kurang baik; namun hal tersebut juga dapat dilakukan secara sengaja oleh penerjemah dalam menjembatani komunikasi antara penutur yang berbahasa Inggris dan audiens yang berbahasa Indonesia. Interferensi dilakukan untuk meredupkan evaluasi negatif yang sebagian besar ditemukan pada ekspresi keberpihakan. Nilai solidaritas lebih ditekankan untuk meminimalisir dampak evaluasi negatif, sehingga keberlangsungan hubungan bilateral Australia-Indonesia dapat diusahakan.

Munday (2012) menyatakan bahwa penerjemah cenderung menyisipkan penilaian atau evaluasinya sendiri sebagai usaha menyaring teks sumber sedemikian rupa, sehingga dampak yang diinginkan pada audiens sasaran dapat dicapai. Interferensi dan distorsi penerjemah di dalam ekspresi keberpihakan dinilai sebagai cara penerjemah membantu melanjutkan hubungan Australia-Indonesia setelah sedikit terganggu oleh eksekusi. Individu dengan kepentingan dan wewenang mempraktikkan posisinya untuk menstabilkan hubungan kedua negara, baik jelas terlihat atau tidak dan disengaja atau tidak. Interferensi dan distorsi penerjemah merujuk terhadap keleluasaan penerjemah dalam menerjemahkan evaluasi penutur teks.

Akhirnya, penelitian ini mengkonfirmasi gagasan Munday (2012) mengenai asersi subyektif penerjemah ketika menerjemahkan teks; dan menambah argumentasi 
Hendrastuti (2013) yang mengasosiasikan interferensi dengan terjemahan kurang akurat.

Tabel 4. Translation Quality of Appraisal Resources in Solidarity and Alignment Expressions

\begin{tabular}{|c|c|c|c|c|c|c|c|c|c|c|c|}
\hline \multirow{3}{*}{ Ekspresi } & \multirow{2}{*}{\multicolumn{5}{|c|}{ Terjemahan Piranti Appraisal }} & \multicolumn{6}{|c|}{ Kualitas Terjemahan } \\
\hline & & & & & & \multicolumn{3}{|c|}{ Keakuratan } & \multicolumn{3}{|c|}{ Keberterimaan } \\
\hline & $=$ & $\gg$ & $\neq$ & - & + & 3 & 2 & 1 & 3 & 2 & 1 \\
\hline Solidaritas & 157 & 13 & 1 & 4 & 3 & 157 & 21 & 0 & 164 & 14 & 0 \\
\hline Keberpihakan & 141 & 14 & 3 & 9 & 4 & 143 & 22 & 6 & 159 & 12 & 0 \\
\hline
\end{tabular}

Interferensi dapat juga menghasilkan terjemahan tidak akurat ketika jumlah piranti appraisal yang mengalami deviasi lebih besar daripada jumlah yang dipertahankan di dalam satu tuturan. Terlebih lagi, interferensi bukan hanya hasil kompetensi penerjemah yang kurang baik: dapat merujuk kepada usaha penerjemah mengaktualisasi tujuan awal teks; meskipun untuk mencapainya pe-nerjemah dapat mengeksploitasi terjemahan sehingga tidak merefleksikan hal yang sama seperti pada teks sumber.

\section{SIMPULAN DAN SARAN}

Terjemahan dapat menimbulkan interferensi atau bahkan distorsi dari pesan teks sumber. Meskipun menurunkan kualitas terjemahan, kedua hal tersebut dapat membantu mewujudkan tujuan awal teks: mempengaruhi audiens untuk berpihak dengan Chan dan Sukumaran, namun tetap berkontribusi menyambung hubungan Australia-Indonesia dengan melakukan deviasi dalam batas tertentu terhadap evaluasi di dalam teks sumber.

Saran untuk penelitian selanjutnya adalah mengamati penerjemahan langsung atau interpreting sebagai penyaring pandangan personal dan politik penutur. Selain mengobservasi proses penerjemahan bahasa evaluasi teks dengan implikasi yang dapat 
diamati pada dunia nyata, interpreting juga memiliki moda dan register yang berbeda sehingga berpotensi memperluas penerapan pola yang dihasilkan oleh studi ini.

\section{REFERENSI}

Bánhegyi, M. 2012. Screening Political Bias and Reality in Media Translation. Translation Journal, 16(3).

Bhatia, V. K. 1993. Analysing Genre: Language Use in Profesional Settings. London/New York: Routledge.

Blackledge, A. 2005. Discourse and Power in a Multilingual World. Amsterdam/Philadelphia: John Benjamins Publishing Company.

Ertyas, C. 2011. An Appraisal Analysis of Gossip News Texts Written by Perez Hilton from Perezhilton.com, Skripsi, Fakultas Ilmu Budaya: Universitas Sebelas Maret.

Hendrastuti, R. (2013). Kajian Penerjemahan Ideologi Dengan Pendekatan Appraisal. International seminar of Language Maintenance and Shift III. Semarang, July 23, 2013, Diakses 15 Desember 2015. Dari http://www.mli.undip.ac.id/ebook/3/International\%20Seminar\%20Proceedings \%20July\%202-3,\%202013/files/assets/basic-html/page420.html.

Hidayani, S. 2006. Appraisals Used in the Dialogues of Oscar Wilde's Drama 'The Importance of Being Earnest'. Tesis, Pascasarjana Linguistik Terapan, Universitas Negeri Semarang.

Hong, Q. 2012. Investigating Translators' Positioning via the Appraisal Theory: A Case Study of the Q\&A Part of a Speech Delivered by the U.S. Vice President Cheney. Sino-US English teaching, 12/2012: 1775-1787. (ISSN: 1539-8072).

Hurst, D. (2015, 18 Februari). "Bali Nine executions: Tony Abbott: Indonesia should reciprocate tsunami aid by sparing Bali Nine pair", The Guardian. Dimodifikasi 18 Februari 2015. Dari http://www.theguardian.com/world/2015/feb/18/tonyabbott-indonesia-reciprocate-tsunami-aid-sparing-bali-nine-pair.

Lee, J. (2015, 29 April). "Indonesia executions: Why Australian anger will outlive political fallout". CNN. Dimodifikasi 29 April 2015. Dari http://edition.cnn.com/2015/04/29/opinions/indonesia-executions-australia/.

Lincoln, Y, S., \& Guba, E. G. 1985. Naturalistic Inquiry. Beverly Hills: Sage Publication.

Martin, J. R., \& Rose, D. 2003. Working with Discourse: Meaning beyond the Clause. London and New York: Continuum. 
Martin, J. R., \& White, P. 2005. The Language of Evaluation--Appraisal in English. Hampshire/New York: Palgrave Macmillan.

Molina, L., \& Albir, A. H. 2002. Translation Techniques Revisited: A Dynamic and Functionalist Approach. Meta: journal des traducteurs/Meta: Translators' Journal, 47(4): 498-512.

Muftihah, A. 2011. A Comparative Study of Appraisal in Your Letters Co-lumn Exposing the Issue of Infotainment Banning Taken from www.thejakartapost.com. Skripsi, Fakultas Ilmu Budaya, Universitas Sebelas Maret.

Munday, J. 2012. Evaluation in Translation: Critical Points of Translator DecisionMaking. New York: Routledge.

Nababan, M., Nuraeni, A., \& Sumardiono. 2012. Pengembangan Model Penilaian Kualitas Terjemahan. Jurnal Kajian Linguistik dan Sastra, 24(1). ISSN 08529604.

Patton, M. Q. 1980. Qualitative Evaluation Methods. Beverly Hills: Sage Publication.

Prasetyo, I. D. 2011. A Comparative Analysis of Appraisal between Editorial and Opinion Column Exposing Ahmadiyah Issue Published in The Jakarta Globe and The Jakarta Post Websites (A study Based on Systemic Functional Linguistics). Skripsi, Fakultas Ilmu Budaya, Universitas Sebelas Maret.

Schäffner, C. 2010. Political Communication Mediated by Translation, dalam Urszula Okulska and Piotr Cap (eds.) Perspectives in Politics and Discourse. Amsterdam/Philadelphia: John Benjamins Publishing Company.

Spradely, J. P. 2006. Metode Etnografi, Yogyakarta: Tiara Wacana; trans. oleh M. Z. Elizabeth dari Ethnographic Methods.

Suherman. 2008. Sistem Appraisal Berita Kriminal Pada Harian Meteor Dan Harian Suara Merdeka, Tesis, Pascasarjana Linguistik, Universitas Diponegoro Semarang.

Sutrisno, A. 2013. Analisis Ungkapan-Ungkapan Sikap Tokoh Utama dalam Novel 'The Body in the Library' Karya Agatha Christie dan Pengaruhnya terhadap Kualitas Terjemahan (Kajian Terjemahan dengan Pendekatan Teori Appraisal). Tesis, Pascasarjana Linguistik Penerjemahan, Universitas Sebelas Maret.

Strauss, A., \& Corbin, J. M. 2003. Dasar-Dasar Penelitian Kualitatif: Tata-langkah dan Tehnik-Tehnik Teoritisasi Data. Yogyakarta: Pustaka Pelajar; trans. oleh M. Shodiq \& I. Muttaqien dari Basics of Qualitative Research: Grounded Research Procedures and Techniques. Thousand Oaks, CA: Sage. 
Umam, R. K. 2014. Analisis Attitude dan Graduation pada Terjemahan Subtitle Film Avatar (Kajian Terjemahan dengan Pendekatan Teori Appraisal). Tesis, Pascasarjana Linguistik Penerjemahan, Universitas Sebelas Maret.

White, P. R. R. 1998. Telling Media Tales: The News Story As Rhetoric. Tesis, Department of Linguistics, Univer-sity of Sydney.

2002. Appraisal--The Language of Evaluation and Stance, dalam Jef Verschueren, Jan-Ola Östman, Jan Blommaert and Chris Bulcaen (eds.), The Handbook Of Pragmatics (pp. 1-27), Amsterdam/ Philadelphia: John Benjamins Publishing Co.

White, P. R. R., \& Sano, M. 2006. Dialogic Positions and Anticipated Audiences--A Framework for Stylistic Comparisons (working paper, 2004), dalam Karin Aijmer and Anne-Marie Simon-Vandenbergen (eds.), Pragmatic Markers in Contrast (Studies in Pragmatics II). Amsterdam/Boston: Elsevier. 